\section{Governance and Upgrading in GVCs: Why does Embeddedness Matter}

\author{
Paulo Jordáo de Oliveira Cerqueira Fortes ${ }^{1}$ \\ ${ }^{1}$ Universidade Federal do Piaui (UFPI), Chefia do Curso \\ de Administração (CCA), Teresina, Brazil \\ Caio Flavio Stettiner ${ }^{2}$ \\ ${ }^{2}$ Fatec Sebrae, Coordenação Curso de Gestão de Negócios \\ e Inovação, São Paulo, Brazil \\ Marcelo T. Okano ${ }^{3}$ \\ ${ }^{3}$ CEETEPS and FGV-EAESP, Master Program in \\ Productive Systems, São Paulo, Brazil
}

Received on

$11 / 29 / 2017$

Approved on

02/13/2019

Responsible editor:

João Maurício Gama

Boaventura

Evaluation process:

Double Blind Review

\begin{abstract}
Purpose - This study's primary objective is to propose actors' embeddedness as a source for governance and upgrading within the GVC (Global Value Chain) framework.

Design/methodology/approach - This study uses co-word analysis to study the GVC scientific production. The analysis is conducted using controversies mapping from the Theory of Scientific and Technological Change (TSTC).
\end{abstract}

Findings - Two theoretical gaps were identified. First, governance and upgrading have more than one definition. Second, value and network are upgrading strategies. This article proposes the use of the Montenegro and Bulgacov (2014) framework to translate governance and upgrading respectively as network governance and strategic outcomes. Embeddedness matters because it is a stable theoretical concept (Granovetter, 1985) that can be a link between network governance and strategic results.

Originality/value - The study's main contribution is to propose relativist embeddedness as a source of governance and upgrading. The second contribution is to present an ANT-based framework to study governance and its strategic results.

Keywords - GVC, Governance, Standards, Upgrading, and Embeddedne

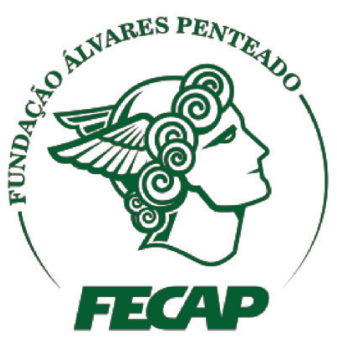

Review of Business Management 


\section{Introduction}

Embeddedness refers to the process by which social relations influence economic activity; it is a network effect (Granovetter, 1992; Uzzi, 1996). Social actors' embeddedness interferes as a source of governance (Jones et al., 1997) and shapes positive and negative network outcomes (Uzzi, 1997).

The concept of embeddedness, as a network effect, is present in two pillars of the Global Value Chain framework: Transaction Cost Economics (TCE) and Network of Governance theory (Humphrey \& Schmitz, 2002a).

The GVC framework uses the work of Powell (1990) with a network form of governance as arm's length or hierarchical relationships, for example (Humphrey \& Schmitz, 2002a). The framework also uses the work of Jones, Hersterly, and Borgatti (1997) to provide network governance parameters.

For Jones et al. (1997), structural embeddedness provides the foundations for social mechanisms to coordinate and safeguard exchanges in network governance. The TCE framework did not integrate the concept of embeddedness (Jones et al., 1997). The authors describe social context as structural embeddedness (Jones et al., 1997). Economic action and its outcomes are affected by actors' relations and by the structures of the overall network relations (Granovetter, 1992).

Network embeddedness is a source for governance and outcomes but it is not a unit of analysis of the GVC framework. The reason is that GVCs are treated as chains rather than networks, but as chains that have sequential production locations and activities.

Governance is central to the GVC framework because controlling production across geographies requires parameters to be set in each activity of each location. The GVC focus is on managing the steps, activities, innovations, technologies, and especially the positive shifts in production. Governance is a value-chain effect and not a network one.
The value-added concept comes from the value-chain proposition. In this proposition, a value chain is a set of activities that a firm performs to deliver valuable products. The global value chain is the result of dividing production activities into different geographies (Porter, 1985).

A shift to more skilled activities is a process combining labor and technology to produce and sell goods (Gereffi, Humphrey, \& Sturgeon, 2005). The word value indicates value added. The term chain denotes different places, materials, technology, and people interacting, before the final product is ready for sale. Raw materials and technology are moved along this chain, adding value in each activity, until the final product is sold to the customer.

The theoretical gap relating to value as value-added does not need addressing. The business sells goods according to their value, and the price and quality are treated when negotiating productions shifts.

The GVC framework employs the value chain approach to set and define upgrading, shifting into more skilled activities (Kaplisnky, 2000; Porter, 1985, 1990); and it uses network theory to determine governance (Jones et al., 1997; Powell, 1990). The GVC framework defines value as value added and the network structure as a chain. The lower presence of the words "value" and "network" in the GVC framework is the result of combining theories.

GVC authors have used embeddedness as an upgrading driver (Pietrobelli \& Staritz, 2013; Staritz \& Morris, 2013). For the authors, embeddedness inserted into the GVC perspective refers to the extent to which firms and owners of firms are enmeshed in local social networks, and how social relations shape economic action (Granovetter, 1985).

Embeddedness, as a network effect, has been tried as a GVC improvement as an upgrading driver, but not as a governance one. The Global Production Network (GPN) framework has incorporated embeddedness as one of its units of analysis, bringing the structural embeddedness 
concept into its framework (Coe, Dicken, \& Hess, 2008; Henderson, Dicken, Hess, Coe, \& Yeung, 2002; Yeung \& Coe, 2015). The GPN framework has imported some of its methods from one version of Actor-Network Theory (ANT) (Law, 1999).

John Law's version of ANT uses semiotic materialism as its ontology. This version of ANT aims at defining actors (Law, 1999). The author uses the plasma unit of analysis instead of the network. The combination of actors is a fluid unit. This version also removes the translations movements of Callon (1986).

The version called "After ANT" (Law, 1999) sees no translations movements since its objective is to define things. The embeddedness of this version, and also of the GPN framework, is better applied to describe the human participation at geographical locations. Humans become a part of the production process.

Law's (1990) version of ANT does not use the network as a unit of analysis, nor does the GPN framework use the premises of ANT regarding causality and power relations. ANT is best used when translating other theories into the sociology of translations (Latour, 2012).

The GPN framework failed to import the controversies as its ontology and maintained the framework as the sociology of the social (Latour, 2012). The result is that the GPN framework has translated ANT into its paradigm, representing a countermovement according to Callon (1986), Law (1990), and Latour (2012).

Embeddedness is a theoretical gap in GVC theory because its structure is represented by a chain and not a network. GPN embeddedness is not an aid for the GVC framework because it does not bring the controversies as ontologies; it does not aim to discover or unravel new agencies.

The GVC framework has explanatory strengths in terms of 20 years of research and already has a paradigm and school of choice. Embeddedness as a network effect can be introduced to help GVC theorists to account for several mediating actors during the formation of governance and upgrading.
ANT can offer versions that were built to describe an action (Callon, 1986; Latour, 2012). The strategizing framework is a version of ANT that has translated network of governance theory and strategy into the sociology of translations (Montenegro \& Bulgacov, 2014).

The strategizing framework has already been tested to describe governance and strategic results (Montenegro \& Bulgacov, 2014). This framework embraces embeddedness since its objective is to unravel the mediation of governance actors in strategic planned actions.

Embeddedness aids GVC theorists to unravel other actors that may affect governance and upgrading, such as the climate or local politics. The strategizing framework allows governance and upgrades to be described in each specific case.

The strategizing framework allows the structure as a network to be described. Researchers may refer to GVCs as business "structures" that "set parameters" for companies. Complying with parameters will lead to "shifting" activities to improve products and processes.

GVCs are structures used to produce and sell goods across the globe (Gereffi et al., 2005). Governance means to set parameters (Humphrey \& Schmitz, 2001) and upgrading means shifts in production activity (Humphrey \& Schmitz, 2002a).

The GVC, or these structures, are the aggregation of several human and non-human actors such as firms, employees, raw materials, technologies, codes, transport, governments, and climate, among others.

Researchers use the GVC framework to better describe how lead firms arrange their resources, production, and sales around the globe. In the GVC framework, the structure depends critically upon three variables: the complexity of transactions, the ability to codify transactions, and the capabilities in the supply-base (Gereffi et al., 2005).

These structures have governances, a term used to express that some firms set and enforce 
the parameters under which businesses operate (Humphrey \& Schmitz, 2001). The connection point between lead firms and local producers are the upgrades. While lead firms seek production at lower costs, smaller producers from less developed countries seek insertion in a global chain.

Commercial deals between buyers and producers require some agreements and parameters to be met from one side and shifts in production from the other side. Upgrading is a structural shift within the GVC to improve products and processes, to move into other activities or into other chains. To upgrade is to make better products more efficiently and to move into more skilled activities (Humphrey \& Schmitz, 2002a).

Upgrading is one of the results of business relationships to produce, process, design, and export goods globally (Humphrey \& Schmitz, 2002a). Companies seek to maintain or increase profits in the face of market pressure and competition. Shifting to more skilled activities or niche markets are examples of upgrading movements.

Governance is not only hard rules that set parameters to be met but also a form of coordination of economic activities. This coordination is essential to provide knowledge and technology transfer, thus favoring innovations (Humphrey \& Schmitz, 2002a). Governance is a tool used by lead firms for determining upgrading opportunities of local producers (Humphrey \& Schmitz, 2002a).

Upgrading requires agreement between several parties, especially between buyers and suppliers. Governance is present at the social level, also referred to as the "social context." Social norms, technologies, culture, and geography are examples of actors that are embedded within the social context (Gereffi et al., 2005).

Embeddedness matters because it affects the structures (GVC), the coordination of parameters (governance), and the shifts in production (upgrading). The social context (norms, geographies, technologies, cultures, governments, laws, taxes, and climate) also affects the shifts in activities (upgrading).
The strategizing framework is already set to investigate governance and its outcomes. Governance is the central focus of the GVC framework, and the strategizing framework (Montenegro \& Bulgacov, 2014) may help GVC by examining the parameters set and the upgrading shifts.

We propose to bring GVC closer to network theory. This is possible by using a version of ANT that has already translated into its framework network of governance theory (Montenegro \& Bulgacov, 2014). The strategizing framework uses Latour (2012) as its basis and embraces the controversies as its ontology.

ANT allows researchers to evaluate how the social elements (humans and non-humans) are embedded when setting the parameters of governance (Montenegro \& Bulgacov, 2014). This version also allows an investigation of which social context actors mediate upgrading shifts.

The strategizing framework does not change the GVC framework, but provides a different point of view regarding the formation of a network of governance and upgrading.

The articles propose to bring network theory closer to GVC theory by using the following definition of network governance (Montenegro, 2013). Network governance would not be a statically defined, predetermined form of governance, but one that would evolve within a GVC. When value and network are removed as the conceptual bases for GVC, the concept of embeddedness better serves GVC to describe governance formation.

The second proposition is to treat upgrading as a strategic governance outcome (Montenegro \& Bulgacov, 2014). This move allows the GVC framework to account for multiple upgrading definitions and to include environmental aspects. For the authors, the human and non-human imbrication is the link between network governance and strategic outcomes (Montenegro \& Bulgacov, 2014).

The final proposition is to explore human and non-human imbrication controversies to 
describe the properties of network governance (actors, mediators, rules, identities) and strategic outcome transformations. Actors' embeddedness controversies are the source of the formation of a network of governance and its strategic outcomes (Montenegro \& Bulgacov, 2014).

\section{Theory of Scientific and Technological Change (TSTC) and the 15+GVC-Framework}

ANT has different versions. Callon (1986) created the sociology of translations version of ANT that uses translations movements to describe actions. Some versions are best employed to translate realities and theories (Latour, 2012; Law, 1999).

Law (1999) created the After ANT version that uses semiotic materialism as its ontology. Latour (2012) created the version of ANT called "Associology", which uses the controversies as its ontology.

The Montenegro and Bulgacov (2014) framework is a version of ANT that translates into its unit of analysis governance and strategic outcomes. The TSTC is a version of ANT that translates the co-word analysis method into its paradigm to describe the process of scientific production (Callon, Law, \& Rip, 1986).

This chapter presents the route used to gather the GVC data to compose an actornetwork of scientific publications. Articles were selected based on their word count of central concepts, such as global, governance, value, chain, upgrading, GVC, producers, buyers, suppliers, and countries. First, we present the TSTC and later the construction of the 15+GVC-framework.

The TSTC was chosen as the theoreticalmethodological approach due to its objective of describing how the forces of science are put together using the co-word analysis method (Callon et al., 1986). The central argument of the TSTC is that understanding social and scientific change requires an abandonment of the dichotomy between science (truth) and politics (power). The production and reproduction of science utilize social interactions. Researchers also need to articulate, or set as devices, several actors when publishing. Articles and papers are reports; they are non-human agents that act in the name of researchers.

This chapter presents the following TSTC units of analysis: actor-network, actor-world, translation, obligatory passage point (OPP), translation centers, black box, enrollment, the funnel of interests, interéssement, and problematization.

This article will focus on the obligatory passage point (OPP) and black box concepts and translations. The strategy allows it to be identified which of the following principal GVC actors are being forced through or placed in between a scientific problem and its solution. Translations mapping was used to recognize which concept or theory is simplified to explain the phenomena scientifically.

An actor-network (AN) is the structure of an operation of an actor-world; an interrelated set of entities that have been successfully translated or enrolled by an actor that is thereby borrowing their force and speaks or act on their behalf or with their support (Callon et al., 1986).

The GVC actor-world has several agents that act in the name of science, theories, paradigms, or/and resources centers. Scientific and technical publications have no power. Instead, power is a result of articulation by another actor. The 15+GVC-framework actor-world has no power. An actor-network's power is the result of several actors' articulations.

Translations are the methods by which one actor enrolls others by defining rules or strategies that are essential by creating an obligatory passage point (OPP) and forcing other actors to follow what has been imposed (Callon, 1986; Latour $\&$ Bastide, 1986).

One of many OPPs of scientific production is the blind-review process, which evaluates matters of science. GVC translation centers are the places where the reviewing and editing processes of science take place.

The GVC translation centers of science are the publishing entities, because they are the locations in which the scientific production 
translation evolves. In these centers attempts by diverse elements of the network and calculations about the return from different strategies are made (Callon et al., 1986). These locations can become the spokespersons for other entities, and in some sense profit from this asymmetry. The principal actors at the $15+$ GVC-framework translation centers are Routledge, Springer, United Nations, Taylor and Francis, the Institute of Development Studies (IDS) at Sussex University, Oxford Academics, the Inter-American Development Bank (IDB), the Institute of Development and Peace, and Elsevier.

The translation centers' spokespersons are: IDS Bulletin, INF Report, World Development, Economy and Society, Review of International Political Economy, UNIDO, Oxford Development Studies, Journal of Economic Geography, IDB Working Paper, Proceedings of National Academy of Science of the United States of America (PNAS), and Journal of Business Ethics. According to the TSTC a theory or a framework has no power; however, it articulates its strengths by borrowing credibility from spokespersons and translation centers (Callon, et al., 1986).

We propose that the $15+$ GVC-framework descriptions will attempt to enroll its actor-world in a specific periodical by providing a convincing argument. The central argument in this article is that embeddedness is a possible OPP between network theory and the GVC framework. OPP embeddedness may allow the GVC framework a theoretical framework for the governance formation process and its mediating actors.

The concept of embeddedness is presented here as an OPP that can better define GVC governance and its outcomes. Presenting embeddedness as a possible GVC framework hero is a way of enrolling this article's readers. To enroll is to establish and distribute roles in an actor-world.

Enrolling a reader allows their interests to be funneled by presenting GVCs' central mediators. This translation is a series of problematizations that ends with a problem-solution. This article proposes that there are gaps in the GVC that have simplified, or black-boxed, into similar network theory concepts. This proposal is called interéssement; that is, the movement of attracting a second actor by coming between that entity and a third.

The problematization of the present article proposes embeddedness as the actor connecting GVC theory and network theory. Problematization is a translation that poses equivalence between two problems; setting an OPP.

This chapter presents the main TSTC arguments and vocabulary. The other detail to be treated is how the $15+\mathrm{GVC}$-framework was produced. The first criterion used to select articles was public availability. The 15+GVC-framework was created based on what is available on Google Scholar at first click. Articles that are not freely accessible were excluded from this research. The criterion aimed to construct a network that is replicable and accessible.

The selection criterion allows the inclusion of what is commonly known; however, it silences articles that can only be reached with advanced databases or with financial exchanges. The plus sign stands for most available.

The plus sign also stands for the most articulated scientific production found. Theory articulation was the article's second selection criterion. Articulated is defined as containing the words that are central to the GVC framework. This search strategy aimed to find texts focused on theoretical GVC building. Thresholds were set as words that repeated in at least $0.6 \%$ of the text: governance, upgrading, standards, networks, production, international, chains, value, global, and globalization

The + sign translates the "most" available articulated scientific production. This strategy was used to define GVC ontologically and epistemologically by what is most accessible. Thresholds allowed the selection of the 15 articles with the highest repetition of central words that are considered central to the GVC framework. However, the threshold was limited to more recent articles where the main focus was GVCs. 
The 15+GVC-framework excluded several articles. The article analysis allowed the conceptual gaps to be described with GVC built ontologically. GVC uses the value-added chain approach and governance theory to explain governances and upgrading within the value chain.

The value-added chain provides a sequential production structure, instead of a network structure. The research conducted before 2001 and later than 2014 showed that no attempt had been made to describe governance and strategic results derived from embeddedness. There were no attempts to use the Latour (2012) version of ANT to guide the GVC research. The idea of embeddedness being the source of governance or upgrading is not new; however, embeddedness is not used as a link between governance and upgrading.

There were some attempts after 2014, such as Barrientos, Knorringa, Evers, and Visser (2015), to draw from GVC and GPN to understand multiple governances. Barrientos, Gereffi, and Picles (2016) propose considering GPN structural embeddedness as a source of upgrading.

For Hernandez and Pedersen (2017), upgrading is a global market outcome. For the authors, language, culture, and regulations may contribute to the embeddedness effect (Hernandez \& Pedersen, 2017). Embeddedness is a possible source of upgrading (Kaplisnky \& Moris, 2016) when foreign owners may interfere in local production.

There is literature that points to embeddedness as the network effect that may help the GVC framework to account for governance and upgrading without changes within the framework. However, the articles found did not use a framework based on Latour (2012), such as Montenegro and Bulgacov (2014), to link this network effect to governance and upgrading.

\section{Methods of Data Production}

Chapter 3 will present the data produced by the TSTC analysis methods in 3 tables. Table
1 shows the GVC mediator words; Table 2 is a relationship matrix between the TSTC unit of analysis (Obligatory Passage Point - OPP and black box); and Table 3 simplifies each scientific production by the TSTC translations.

Law (1986) states that laboratory activity needs to juxtapose, simplify, and routinize. Tables and graphs are the main simplifications seen in scientific production. Tables with data allow researchers to simplify facts and readers to check the consistent production of data-based arguments. This chapter presents three tables with the produced data. Table 1 below represents the initial GVC mediators.

Word count software (MAXQDA, 2017) was used to count repeated words in each article. A relationship matrix was created corresponding to article actor-worlds. The actor-worlds were combined in a co-word matrix to produce the 15 most articulated words within the database, giving rise to Table 1 .

The second database produced is the identification of OPPs and black boxes. According to TSTC (Callon et al., 1986), in problematization translation there are generally traces of the OPP and the black box (Table 2). The articles analyses allowed for the main translations (Table 3) to be identified, as well as what each article proposes.

Table 2 results from matching OPPs and black boxes that allowed researchers to produce descriptions of the 15+GVC-framework displacements. In the following chapters, data table triangulations will enable mapping of the dynamics of GVC theory building, within the 15+GVC-framework, from 2001 to 2014.

According to the TSTC (Callon et al., 1986), the most repeated words of an article describe what each actor-world articulates; they are the article's mediators (Table 1). However, a higher word count does not always mean mediation. Table 3 presents the 15 articles' actor-worlds units of analyses (translation center, enrollment, the funnel of interests, interéssement, and problematization). 
Table 1

\section{5+GVC-framework co-word database}

\begin{tabular}{|c|c|c|c|c|c|c|c|c|c|}
\hline Co-Words & & & & & Year & & & & \\
\hline & 2001 & 2002 & 2005 & 2006 & 2008 & 2010 & 2012 & 2014 & Total \\
\hline Chains & 155 & 240 & 402 & 192 & 286 & 31 & 48 & 104 & 1458 \\
\hline Global & 74 & 194 & 270 & 96 & 261 & 43 & 28 & 282 & 1248 \\
\hline Value & 50 & 124 & 321 & 171 & 155 & 62 & 27 & 132 & 1042 \\
\hline Governance & 54 & 150 & 131 & 54 & 254 & 46 & 18 & 135 & 842 \\
\hline Firms & 78 & 193 & 190 & 33 & 131 & 46 & 26 & 113 & 810 \\
\hline Standards & 51 & 67 & 46 & 160 & 248 & 26 & 97 & 29 & 724 \\
\hline Upgrading & & 183 & 193 & 17 & 100 & 32 & 18 & 154 & 697 \\
\hline Markets & 75 & 128 & 136 & 106 & 10 & & 42 & 52 & 549 \\
\hline GVC & & & 34 & 16 & 205 & 69 & 10 & 210 & 544 \\
\hline Products & 49 & 162 & 149 & 102 & 24 & 10 & 24 & & 520 \\
\hline Development & 25 & 76 & 76 & 58 & 92 & 40 & & 120 & 487 \\
\hline Industry & 15 & 79 & 104 & 36 & 109 & 31 & & 95 & 469 \\
\hline Suppliers & & 80 & 138 & 69 & 92 & 39 & & 44 & 462 \\
\hline Production & 35 & 69 & 97 & 82 & 75 & 26 & 14 & 60 & 458 \\
\hline
\end{tabular}

Table 2

\section{5+GVC-framework OPP and black box matrix from 2001 to 2014}

\begin{tabular}{|c|c|c|c|c|c|}
\hline Black Box & Obligatory Passage Point OPI & & & & \\
\hline & Governance & Convention Theory & TCE & Trends & GVC Framework \\
\hline GPN Structure & Gereffi (2001) & & & & \\
\hline Patterns & Humphrey and Schmitz (2001) & & & & \\
\hline Upgrading & $\begin{array}{l}\text { Humphrey and Schmitz } \\
\text { (2002a) Giuliani, Pietrobelli, } \\
\text { and Rabellotti (2005), Gereffi } \\
\text { and Lee (2014) }\end{array}$ & & & & \\
\hline Governance & $\begin{array}{l}\text { Humphrey and Schmitz } \\
\text { (2002b) Gibbon, Bair, and } \\
\text { Ponte (2008) }\end{array}$ & & $\begin{array}{l}\text { Gereffi } \\
\text { et al. (2005) }\end{array}$ & & \\
\hline Quality & & $\begin{array}{l}\text { Ponte and Gibbon } \\
(2005)\end{array}$ & & & \\
\hline Standards & Nadvi (2008) & & & $\begin{array}{l}\text { Humphrey and } \\
\text { Memedovic (2006) }\end{array}$ & $\begin{array}{l}\text { Lee, Gereffi, and } \\
\text { Beauvais, (2012) }\end{array}$ \\
\hline Tech. Capabilities & & & & & $\begin{array}{l}\text { Morrison, Pietrobelli, } \\
\text { and Rabelloti (2008) }\end{array}$ \\
\hline Innovations & & & & & $\begin{array}{l}\text { Pietrobelli and } \\
\text { Rabellotti (2010) }\end{array}$ \\
\hline $\begin{array}{l}\text { International } \\
\text { Development }\end{array}$ & & & & & Gereffi (2014) \\
\hline
\end{tabular}

After refining the data, it is possible to deploy actor-worlds translations. According to the TSTC, a published article is the successful result of several translations. When using translations of a different actor-world jointly, some translations are successful and others are not. This analysis method of deployment of translations will allow contradictions to be mapped in chapter 4 .

The database in Table 3 contains a description of what each actor-world articulates and it was used to identify $15+$ GVC-framework OPPs and black boxes presented in Table 2. The matrix will be used to match article articulations. 


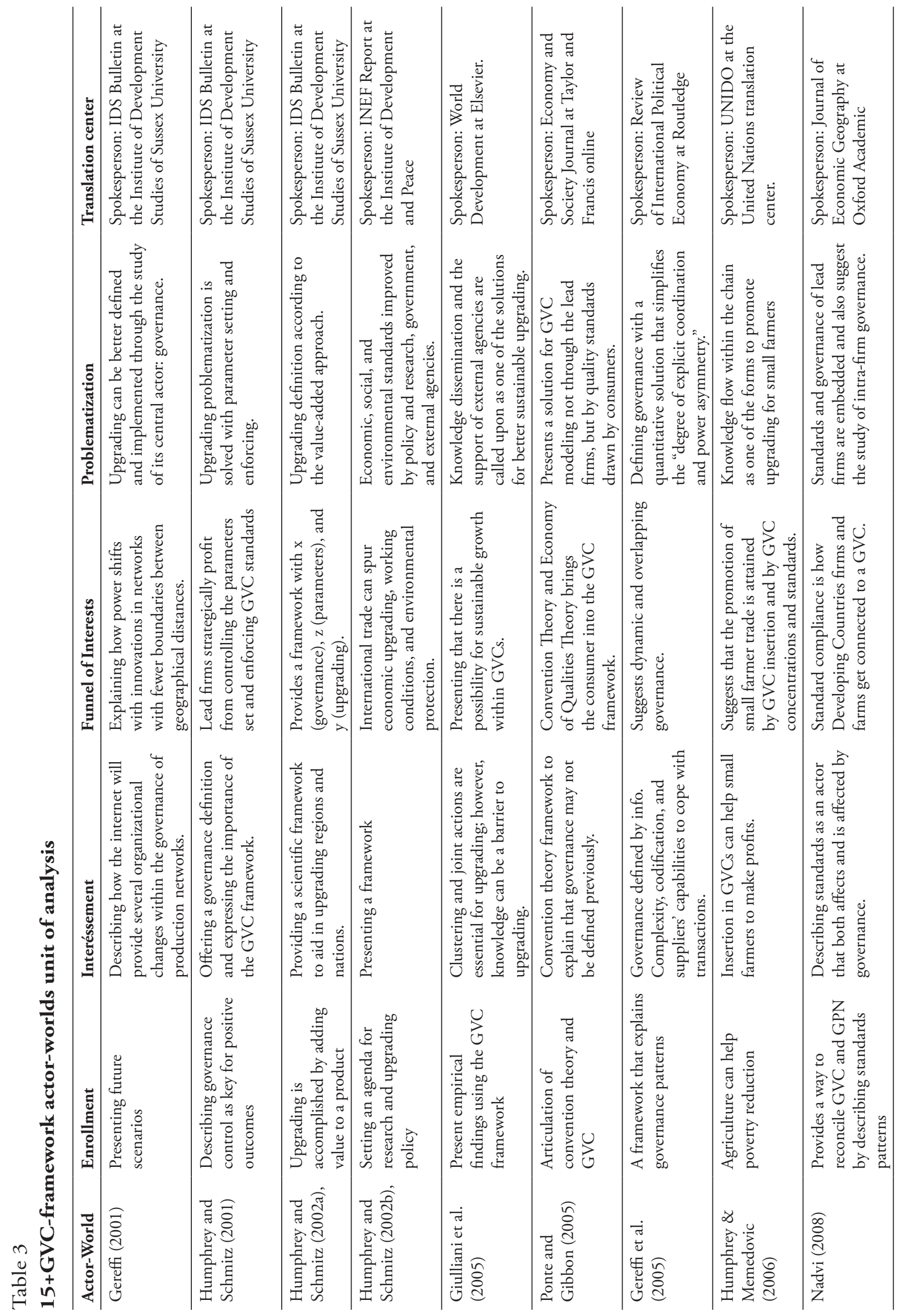




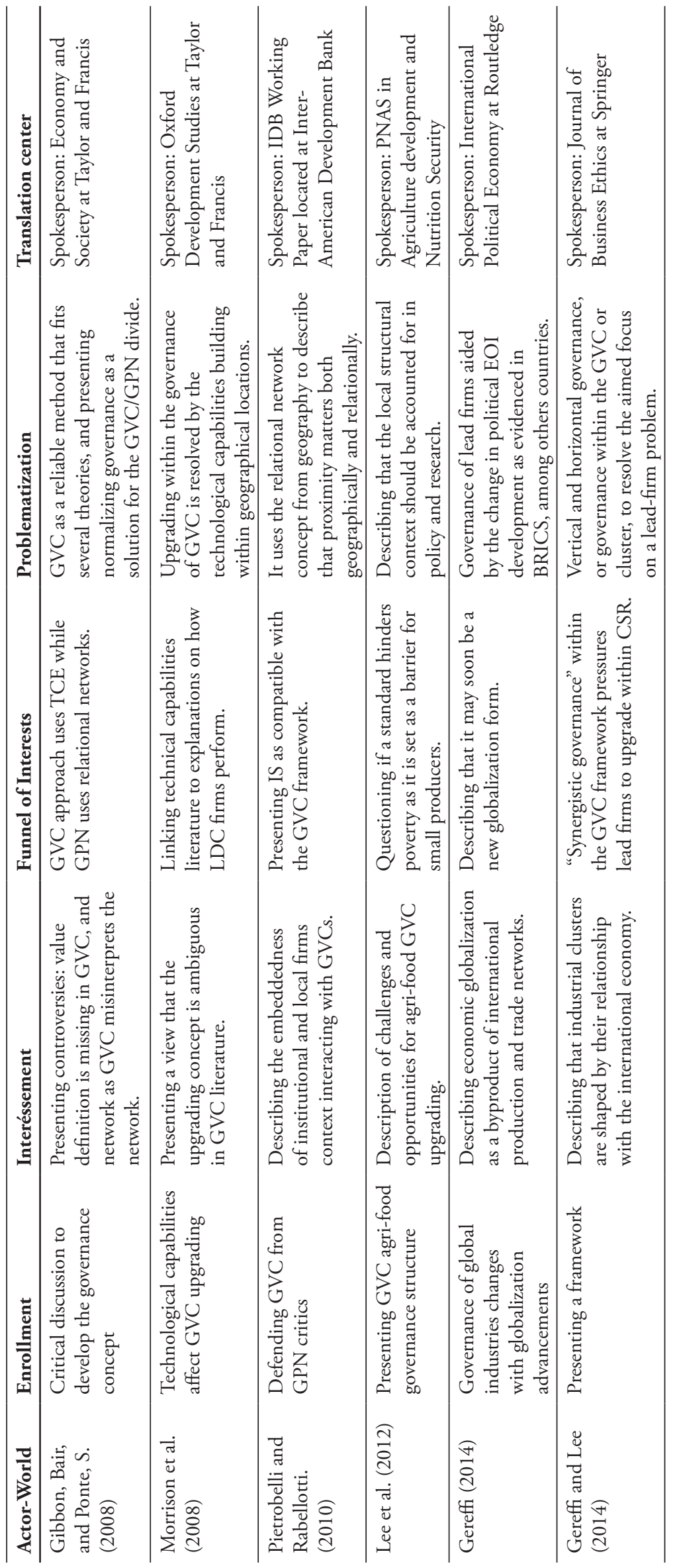




\section{Data Analysis and Results}

The data produced will be analyzed by triangulating the tables' findings. The database, in Table 1, contains the GVC mediator words organized from 2001 to 2014. The words global, value, and chain are the principal mediators used to find the articles. Governance, standards, upgrading, firms, and markets are the mediating words that are used to define GVC (the Global Value Chain).

Products, development, industry, suppliers, production, cluster, countries, buyers, and local are words used to set the context of the 15+GVC-framework and its participants. The word governance was repeated 842 times (Table $1)$. It is the actor-network mediator offered as the OPP for eight articles from 2001 to 2014 . It is the black box for three articles from 2002 to 2006 (Table 2).

The word standard is repeated 724 times (Table 1) and is the actor-network black box for three articles from 2006 to 2012 (Table 2). Upgrading was repeated 697 times (Table 1) and is offered by the actor-network as the black box of 3 articles from 2002 to 2014 (Table 2). GVC was repeated 544 times (Table 1) and is offered by the actor-network as the OPP of 4 articles between 2008 and 2014 (Table 2). Firms have a high count of 810 ; however, it is not considered a mediator in this analysis. It is neither an OPP nor a black box in Table 2 .

The 15+GVC-framework used governance as its main OPP between 2001 and 2008 and used GVC as its main OPP between 2008 and 2014. Standards (in 2006 and 2012) and upgrading (between 2002 and 2005) are black boxes. The 15+GVC-framework describes the route of GVC theory building by first using governance to explain upgrading from 2002 to 2008; in 2005, other concepts or theories were brought into the GVC framework, such as quality, standards, TCE, and convention theory.

From 2005 to 2010, attempts were made to enlarge the lead-firms view with the GPN approach and to criticize (Gibbon et al., 2008) and to defend (Giuliani et al., 2010) the GVC construct (see Table 3 enrollments). GVC became an OPP in 2008 as a theory that contains enough historical data to answer questions regarding the globalization of industrial production and has as a main argument that the governance of lead-firm upgrading is explained within the GVC.

For this research, the 15+GVC-framework is an actor-network composed of authors, theories, journals, words, storage sites, search engines, universities, international organizations, firms, clusters, technologies, and knowledge, among other actors. It travels through time and space translating new actors into its network, to explain, through the lens of lead-firm governance, which is the best way for producers in developing countries to join the international market sustainably. This definition describes what the $15+$ GVCframework is and what it articulates, but what controversies does this actor-network hold?

According to Callon (1986), controversy is an excellent way to describe a field. For the author, scientists should use controversies mapping to specify a domain, theory, or argument appropriately. This chapter will use the data produced to map controversies using translations deployments.

Advancement in GVC theory can be noted by comparing the actor-world of Gereffi (2001) with that of Gereffi (2014), in Table 2. Gereffi (2001) used governance, as the OPP, and structures of production networks, as a black box, to explain how power shifts along the chain. Gereffi (2014) simplified the international development outcomes by using the GVC framework. Governance explained structures in 2001 while the GVC explained international outcomes in 2014.

The theory advancements and findings from 2014 are comparable with the ones from 2001. In 2014, Gereffi (2014) overcame the problems of lack of governance control faced by small producers in 2001 with the exportoriented industrialization (EOI) model. The 
industrialization model proposed also focuses on local and regional markets (Gereff, 2014) (see Table 3 problematization).

Another description of this actor-network is the different set between 2005 and 2010 showing criticisms, defenses, and solutions (see Table 3 enrollments). Gereffi et al. (2005) present the GVC framework as a theory (see Table 3 problematization) by using the discipline of Transaction Cost Economics (TCE) as the OPP and by black boxing the critical determinants of governance.

In the same year, Ponte and Gibbon (2005) defined this differently from Gereffi et al. (2005) (see Table 3 problematization). Humphrey and Memedovic (2006) continue the theory building using GVC by suggesting trend studies as OPPs. The two major trends are standards and concentration. The direction setting for poverty reduction is government aid for small producers to enter an international chain and to promote knowledge flow within the GVC (see Table 3 enrollment).

Gibbon et al. (2008) present another criticism by using governance as an OPP and simplifying the governance forms. This aims to unify frameworks. Gibbon et al. (2008) conclude that GVC fits different paradigms as methods (see Table 3 problematization). However, Nadvi (2008) discretely resolves the divide between international political economy and economic geography by using governance as the OPP and black boxing standards (see Table 3 enrollment). Nadvi (2008) was able to draw conclusions based on the works of both Gereffi et al. (2005) and Ponte and Gibbon (2005).

The discussion will now treat the linkage between governance, standards, and upgrading. Standard is one of the most articulated words (Table 1) linking governance to upgrading. However, governance alone continues to not fully explain upgrading, as suggested by Pietrobelli et al. (2010), who defined innovations systems (IS) compatible with GVC. For the authors, GVC is in constant evolution, and it builds on criticisms of GPN that relational proximity may be as useful as geographical proximity (see Table 3 problematization).

This article's position is that GVC and GPN theorists continue working on science building blocks, complementing the theory with their own theoretical embedded background. The origins of those theorists' conflicts are not in the GVC theory, but the political economy and economic geography paradigms. Both academies have noble reasons for improving upgrading conditions in LDCs.

Upgrading was the seventh most repeated word (Table 1). Humphrey and Schmitz (2002a), building on competitive strategy theory, found that the most viable way to obtain trade returns lies in the upgrade definition (see Table 3 enrollment).

The upgrade definition of "make better products, make them more efficiently, and move into more skilled activities" of Porter (1990) and Kaplinsky (2000) has also employed other actors while defining and classifying upgrading. The controversy is that the definition of upgrading moved from an economic strategy (Humphrey \& Schmitz, 2002b) (see Table 3 enrollment) to the capacity of a firm to innovate and to increase the value added to its products and processes, as in Giuliani et al. (2005). Morrison et al. (2008) contribute to the upgrading critiques while arguing that chain governance may be complemented by the technological capabilities approach to better explain upgrading (see Table 3 enrollment).

One controversy with the upgrading definition used by the 15+GVC-framework from 2002 to 2014 is that the definition ties both upgrading and value, where value adding is the most viable strategy for upgrading. Value is the second most repeated word (Table 1), however poorly articulated by GVC theory (not in Table 2), as noted by Gibbon et al. (2008) (see Table 3 interéssement).

Value adding is not the only GVC upgrading strategy; networking is another 
solution for upgrading, as noted by Humphrey and Schmitz (2002b). Network is not a word classified as a mediator in the 15+GVC-framework due to its lower count (not in Table 1) and due to its smaller articulation (not in Table 2). The controversy is that value and network concepts are not well articulated but offered as a solution for upgrading.

The 15+GVC-framework has included social standards since 2002. In 2005, the high road and low road strategies for upgrading of Giuliani et al. (2005) took the latter form of social upgrading and downgrading in Gereffi (2014). The solution for the construct enlargement accounted for vertical governance within the value chain and horizontal governance within the cluster (see Table 3 problematization). Gereffi and Lee (2014) consider it the most robust framework; however, the problem of multiple joint governances acting upon upgrading remains unresolved.

Gereffi and Lee (2014) use the Barrientos, Gereffi, and Rossi (2011) definition of upgrading, which refers to the process of improving the rights and entitlement of workers as social actors and enhancing the quality of their employment. The authors also use Oliveira's (2008) routes for social upgrading in their framework for an economic and social upgrade.

The controversy is that the social upgrading described by Barrientos et al. (2011) black boxes standards; so if social standards increase, upgrading also increases. For Oliveira (2008), social upgrading refers to long-term strategies to improve social and environmental standards. The author points to the inseparability of social and environmental upgrading. Upgrading has different definitions, where in Barrientos et al. (2011) better standards result in upgrading, and in Oliveira (2008) upgrading results in better standards.

The main conclusion of this chapter is that governance and upgrading are theoretically tied. We described the theoretical gaps found by presenting controversies. Governance and upgrading definitions are the main gaps identified in this chapter. The word standard is also a link to both central GVC concepts but is not a mediator concept. The following section will offer an approach for bringing it closer to network theory and discusses the gaps in the $15+$ GVCframework.

\section{Discussion: How to Fill the 15+GVC-Framework Gaps}

The first gap addressed in the previous chapter is the articulation of concepts of value and network. The words network and value are not mediators (not present in Table 2), and their lower presence is due to their ontological natures. Value is a concept imported from the vale-added chain and a sequential chain instead of a network represents the GVC structure (Porter, 1985). The value, as value added, must remain in the GVC framework to link governance structures to shifts in production.

This section will move on to address governance and upgrading. The explanatory strength of GVC theory is that global value chain governance can be black boxed, and with this theory simplification it is possible to predict governance forms and outcomes. The movement of using network theory to help fill possible GVC gaps needs a vocabulary approximation.

This article's proposal is to translate governance as a network of governances and to translate upgrading as outcomes, but before translating definitions into network theory vocabulary, this research has to point out the need to combine different epistemologies.

Klijn, Steijn, and Edelenbos (2010) define governance networks as stable patterns of social relations between mutually dependent actors. The authors point out that network governance outcomes are strongly related to network management.

For Fawcett and Daugbjerg (2012), outcomes are conditioned by both network structure and management. The explanation of governance outcomes needs a combination of 
the Network Governance (NWG) and Policy Network Analysis (PNA) schools. The authors point out that for the PNA school power is exercised by the exclusion of actors and by the institutionalization of policy problem solving, and for the NWG school governance outcomes are affected by a broader context within which they are embedded. Both schools' findings are necessary to translate the central mediator because the definition links lead-firms' power and upgrading results, where GVC governance is:

“... a centerpiece of GVC analysis. It shows how corporate power exercised by global lead firms actively shapes the distribution of profits and risks in an industry, and how this alters the upgrading prospects of firms in developed and developing economies that are included as well as excluded from the supply chains that constitute each industry" (Gereffi \& Lee, 2014, p. 28).

Network theory authors also use the word governance. Rhodes (1997) is an author whose findings are employed by PNA and NWG, and he describes that governance refers to governing with and through networks. For Bevir and Rhodes (2006), network governance is the stories that people use to construct, convey, and explain traditions, dilemmas, and practices. For the authors (Bevir \& Rhodes, 2006; Rhodes, 1997), network is not a given set of characteristics; they apply no comprehensive account of network governance since it lacks essential properties. For the authors, narratives better describe governance.

The second translation proposed defines upgrading as an outcome, since the $15+$ GVCframework articulates upgrading as an expected result. Upgrading is aimed at a result through specific governance. The outcome translation allows an approximation of network perspectives that use governance as the black box to offer explanations, and perspectives that use TCE as an OPP to offer explanations (see Table 3 and Table 2).

One approximation is the works of Gereffi and Lee (2014) and Provan and Kenis
(2007). The first author black boxes governance as participant-governed, lead-organization, and network administrative organization, while the latter authors black box governance as private, social, and public. For Provan and Kenis (2007), organizational effectiveness may be a governance outcome. This approximation may not be feasible due to structural differences; however, in a political epistemology, the ontologies constraint must be avoided.

Another approximation is that of Gereffi et al. (2005) and Jones et al. (1996). The first authors use TCE as an OPP to describe in which conditions governance emerges and thrives, while the second authors use TCE as an OPP to define governance by the degree of explicit coordination and power asymmetry. For Jones et al. (1996), networks of governance are mechanisms for exchange. This view may help GVC theory by providing directions for lead-firm governance improvements.

Network governance is not a static concept but rather a dynamic one (Jones et al., 1997). It is an actor that emerges and thrives (Provan \& Kenis, 2007) and for which there is no comprehensive account (Bevir \& Rhodes, 2006; Staritz \& Moris, 2013). Network governance translation to GVC theory vocabulary may require the abandonment of black boxing the organization as either market or hierarchies, but instead as a network organizational form.

Network forms of organizations are a collection of actors that repeat exchanging transactions in which dispute-solving arises within the exchange (Poldony \& Page, 1998). For the authors, network is neither the combination nor the hybridization of both TCE (hierarchies) and principal-agent theory (markets); it is instead an organizational form. Network governance theory embraces embeddedness as a crucial actor for understanding network outcomes. This direction may help GVC theory by providing an understanding of the embeddedness of governance and upgrading actors, as in Gereffi and Lee (2014). 
For Uzzi (1996), embeddedness refers to the process by which social relations shape economic action, and the embeddedness outcomes are not unconditionally beneficial. The author argues that social structure governs the intervening processes that regulate essential performance outcomes, both positive and negative (Uzzi, 1997). Structural embeddedness provides the foundations of social mechanisms (Jones et al., 1996), referring to embeddedness as one of the sources of governance. The concept of embeddedness may help GVC theory by providing explanations of how downgrading, as a governance outcome, may be created unconditionally.

Vertical and horizontal governances (Gereffi \& Lee, 2014) shape economic action for both social and economic upgrading. Social relations form governances, for example in CSR actions, where corporations represent society's interests. One of the outcomes governance aims for is upgrading; however, downgrading is a possible outcome as well. In the 15+GVC-framework, governance and upgrading/downgrading are embedded.

Embeddedness may also help the GVC theory by providing explanations of how actors handle their actions within the firm's "governance structure" instead of dealing in complex negotiations (Granovetter, 1985). For the author, most behaviors are closely embedded in networks of personal relations.

The argument tries to avoid atomized views of theories of action, and the neoclassical view makes little attempt to provide a general understanding of outcomes as growth, inflation, and unemployment (Granovetter 1985). In the definition of embeddedness of Granovetter (1985), the agent identities, interests, and objectives are variable outcomes, meaning that the agent is neither immersed in the network nor framed by it.

Embeddedness matters for GVC theory since the global value chain approach describes the governances and outcomes of industrialization in past decades. The actions behind upgrading are deeply socially embedded with EOI models, lead-firm strategies, poverty reduction strategies, academic disciplines, paradigms, and standards (economic, social, and environmental).

This research points out that governance and upgrading definitions are theoretically embedded. The suggestion is to define the concept of governance as an OPP between GVC theory and network theory. Governance needs to be translated as a network of governance.

Translating existing definitions may provide theoretical progress in GVC and network theory. However, theoretical advancement may not be achieved only by matching governance from distinct approaches, but also by translating GVC governance into the theory of network governance.

Network governance takes form in different instances (organizational, inter-organizational, and institutional) and compounds the social context in which it is formed by the imbrication of human actors and non-human actors, thus also constituting a relevant non-human actor (Montenegro, 2013).

The proposed definition of Montenegro (2013) below could be used to redefine the GVC governance of Gereffi and Lee (2014) presented earlier in this chapter: "Networks of governance are complex and dynamic. They may have characteristics such as interdependence, exchanges of resources and information, and relative autonomy" (translation of Montenegro, 2013, p. 164).

Actor-network theory (ANT) is used as an OPP, and network and strategy disciplines as a black box, to redefine governance. It enrolls its readers by offering a new governance definition built on Rhodes (1997). It funnels the reader's interests by delineating a methodological approach to understand governance outcomes, and it creates interest in readers by combining strategy and network sciences in one specific translation. The authors' problematization is an analytical framework offering. 
For Montenegro and Bulgacov (2014), an actor's embeddedness and its controversy must be explored to describe the routes of human and non-human imbrication. Networks of governance are not at the center of the analysis, but just one of its units. The strategizing framework sets the network of governance, human and non-human actors, and strategic outcomes as the units of analyses.

Actor embeddedness controversies will be the source feeding networks of governance and strategic outcomes. Embeddedness provides a theoretical source for networks of governance (Jones et al., 1996), theoretical bases for positive and negative outcomes (Uzzi, 1996; Uzzi, 1997), and a theoretical perspective to avoid atomized views that frame outcomes as something predetermined by definition (Granovetter, 1985).

The Montenegro and Bulgacov (2014) framework can be used to frame which specific actors act upon distinct networks of governance and which outcomes are strategy generated (upgrading/downgrading). GVC standards may be one of the essential non-human actors. Researchers' contributions to GVC theory should carefully disentangle governance and upgrading.

\section{Conclusions}

The central question is: what is the interest of GVC theory, and what is its aim? The answer is to control (governance) adverse industrial outcomes (downgrading) and promote better positive industrial outcomes (upgrading) using parameter setting (standards). One of the conclusions is that the $15+$ GVC-framework aims to articulate industrial development across nations within its network of relations (universities, research centers, international organizations, banks).

The enrollment translation was key in describing the contradictions between the actorworlds because it is the distribution of roles of an actor-world; when deployed within other actorworlds enrollment might not be valid, leading to a contradiction description. Problematization translation was used to settle disputes to a specific field of resolution. Another conclusion is that the analyzed actor-network articulated power results from borrowing forces from its translation centers and its spokespersons.

This research's fragility lies first in the inability of TSTC to provide explanations; however, TSTC can set a discussion vocabulary and a strategy for science mapping. Secondly, this research focused only on the most articulated GVC scientific production, leaving silent several other possible solutions. Thirdly, the value and network gap were not addressed.

Governance and upgrading are the central GVC concepts, and both have controversial definitions. Standard is a concept linking GVC governance to upgrading; however, this concept has a controversial meaning. Gereffi and Lee's (2014) articles use perspectives defining upgrading as a cause (Barrientos et al., 2011) and upgrading as a result (Oliveira, 2008). This non-settlement leads to the conclusion that GVC is a theory in evolution, as noted by Pietrobelli and Rabelloti (2010).

This article proposes two translations from GVC concepts into network theory concepts. The first is to translate governance as a network of governance while the second is to translate upgrading as outcomes. This translation will first enable an approximation between both theories and second allow downgrading to not only be treated as a non-intentional side effect.

Actor embeddedness (Granovetter, 1985) will become the source of a network of governance and its outcomes. This conclusion is aligned with previous GVC scientific production using local embeddedness as an upgrading driver (Pietrobelli \& Staritz, 2013; Staritz \& Morris, 2013).

The main conclusion is that embeddedness matters for the $15+$ GVC-framework because the economic action within the GVC is affected socially and because GVC concept creations transport different paradigms. Embeddedness is a possible link between GVC and network theories, and the discussion should advance on this actor- 
network. Governance theory may help the GVC construct by providing theoretical explanations regarding upgrading as a governance outcome.

Network theories can better aid the 15+GVC-framework by focusing on GVC construct embeddedness concepts of governance, standards, and upgrading/downgrading. The discussion points to the strategizing framework (Montenegro \& Bulgacov, 2014) as a possible contributor to GVC theory advancements.

\section{References}

Barrientos, S., Gereffi, G., \& Rossi, A. (2011). Economic and social upgrading in global production networks: A new paradigm for a changing world. International Labour Review, 150(3-4), 319-40.

Barrientos, S., Knorringa, P., Evers, \& B., Visser, M. (2015, November 26). Shifting regional dynamics of global value chains: Implication for economic and social upgrading in African horticulture. A Environment and Planning, 1-18. doi: 10.1177/0308518X15614416

Barrientos, G., \& Picles, J. (2016). New dynamics of upgrading in global value chains: Shifting the terrain for suppliers and workers in the Global South. Environment and Planning, 48(7) 12141219.

Bevir, M., \& Rhodes, R. A. W. (2006). Governance Stories. London: Routledge.

Callon, M. (1986). Some elements of a sociology of translations: Domestication of the scallops and fishermen of St. Brieuc Bay. In J. Law (Ed.) Power Action and Belief: A new sociology of knowledge (pp. 196-223). London: Routledge and Kegan Paul.

Callon, M., Law, J., \& Rip, A. (Eds.) (1986). Mapping the dynamics of science and technology. London: The Macmillan Press LTD.

Coe, N. M., Dicken, P., \& Hess, M. (2008). Global production networks: Realizing the potential. Journal of Economic Geography, 8(1), 271-295.

Fawcett, P., \& Daugbjerg, C. (2012). Explaining governance outcomes: Epistemology, network of governance and policy network. Political Studies Review, 10, 195-207.

Gereffi, G. (2001). Beyond the producer-driven/ buyer-driven dichotomy: The evolution of the global value chains in the internet era. IDS Bulletin, 32(3), 30-40.

Gereffi, G., Humphrey, J., \& Sturgeon, T. (2005). The governance of global value chains. Review of International Political Economy, 1(12), 70-104.

Gereffi, G. (2014). Global Value Chains in a post-Washington consensus world. Review of International Political Economy, 1(21), 9-37.

Gereffi, G., Lee, J. (2014). Economic and social upgrading in global value chains and industrial clusters. Journal of Business Ethics, 133(1), 25-38.

Gibbon, P., Bair, J., \& Ponte, S. (2008). Governing global value chains: An introduction. Economy and Society, 37(3), 315-338.

Giuliani, E., Pietrobelli, C., \& Rabellotti, R. (2005). Upgrading in global value chains: Lessons from Latin American clusters. World Development, 33(4), 549-573

Granovetter, M. (1985). Economic action and social structure: The problem with embeddedness. The American Journal of Sociology, 91(3), 25-56

Granovetter, M. (1992). Network and organizations: Structure, forms and action. The Harvard Business Press, 25-56.

Henderson, J., Dicken, P., Hess, M, Coe, N., \& Yeung, W. C. (2002). Global production networks and the analysis of economic development. Review of International Political Economy, 9(3), 436-454. 
Hernandez, V., \& Pedersen, T. (2017) Global value chain configuration: A review and research agenda. Business Research Quarterly, 20, 137-150

Humphrey, J., \& Memedovic, O. (2006). Global value chain in the agri-food sector. UNIDO Working Paper, 1-54. Vienna. Retrieved from https://www.unido.org/sites/default/ files/2009-05/Global_value_chains_in_the_ agrifood_sector_0.pdf

Humphrey, J., \& Schmitz, H. (2001). Governance in Value Chains. IDS Bulletin, 32(3), 19-29.

Humphrey, J., \& Schmitz, H. (2002a). How does the insertion in global value chains affect upgrading in industrial clusters? Regional Studies, 36(9), 1-16.

Humphrey, J., \& Schmitz, H. (2002b). Developing countries firms in the world of economy: Governance and Upgrading in Global Value Chains. INEF Report, 61, 1-35.

Jones, C., Hersterly, W. S., \& Borgatti, S. P. (1997). A general theory of network governance: Exchange conditions and social mechanisms. Academy of Management Review, 22(4), 911-945.

Kaplinsky, R. (2000). Globalization and unequalization: What can be learned from value chain analysis? Journal of Development Studies, $37(2), 117-46$.

Kaplinsky, R., \& Moris, M. (2016). Thinning and thickening: Productive sector policies in the era of global value chains. European Journal of Devolpment Research. 28(4), 625-645.

Klijn, E. H, Steijn, B., \& Edelenbos, J. (2010). The impact of network management strategies on the outcomes in governance networks. Public Administration, 88(4), 1063-1082.

Latour, B., \& Bastide, F. (1986). Writing sciencefact and fiction: The analysis of the process of reality construction through the application of socio-semiotic methods to scientific texts. In B. Latour, \&, F. Bastide(eds.). Mapping The Dynamics of Science and Technology (Cap. 4, p. 51 - 66). London: The Macmillan Press LTD.

Latour, B. (2012). Reassembling the social. London: The Macmillan Press LTD.

Law, J. (1986) Laboratories and Texts. In Callon, M., Law, J., Rip, A. (Eds.). Mapping the Dynamics of Science and Technology. London: The Macmillan Press LTD.

Law, J. (1999). After ANT: Complexity, naming and typology. In J. Law, J. Hassard (Eds.), Actor Network Theory and After (pp. 1-14). Oxford: Blackwell.

Lee, J., Gereffi, G., \& Beauvais, J. (2012). Global value chains and agri-food standards: Challenges and possibilities for smallholders in developing countries. PNAS, 109(31), 12326-12432.

MAXQDA (2017). (Version 12.1) [software for qualitative data analysis], Berlin: VERBI Software.

Montenegro, L. M. (2013). Um parlamento de Múltiplos Atores: Um estudo sob a perspectiva da teoria ator-rede para o entendimento da governança e dos resultados estratégicos de cursos de graduação em administração de instituiçóes de ensino particulares de Curitiba (Doctoral Dissertation). Universidade Federal do Paraná - UFPR, Curitiba, PR, Brazil.

Montenegro, L. M., \& Bulgacov, S. (2014). Reflections on Actor-Network Theory, governance networks, and Strategic Outcomes. Brazilian Administration Review, 11(1), 107-124.

Morrison, A., Pietrobelli, C., \& Rabelloti, R. (2008). Global Value Chains and technological capabilities: A framework to study industrial innovation in developing countries. Oxford Development Studies, 36(1), 1-27.

Nadvi, K. (2008). Global standards, global governance and the organization of global Value Chains. Journal of Economic Geography, 8(3),1-21. 
Oliveira, J. A. P. de, (Ed.) (2008). Upgrading clusters and small enterprises in developing countries: Environmental, labor, innovation and social issues. Hampshire: Ashgate Publishing.

Pietrobelli, C., \& Rabellotti, R. (November 2010). Global value chains meet innovations systems: Are there learning opportunities for developing countries? Inter-American Development Bank, 232, 1-24.

Pietrobelli, C., \& Staritz, C. (May 2013). Challenges for global value chain interventions in Latin America. Inter-American Development Bank, Competitive and Innovation Division. III, Title IV, Serie IDB-TN-548.

Poldony, J. M., \& Page, K. L. (1998). Network forms of organization. Annual Review of Sociology, 24, 54-76.

Ponte, S., \& Gibbon, P. (2005). Quality standards, conventions and the governance of global value chains. Economy and Society, 34(1), 1-31.

Porter, M. (1985). The competitive advantage: Creating and sustaining superior performance. New York: Simon and Schuster.

Porter, M. (1990). The competitive advantage of nations. London: Macmillan.

Powell, W. (1990). Neither market nor hierarchy: Networks forms of organizations. Research in Organizational Behavior, 12(1), 295-336.
Provan, K. G., \& Kenis, G. (2007). Modes of network governance: Structure, management, and effectiveness. Journal of Public Administration Research and Theory, 18(2), 229-252.

Rhodes, R. A. W. (1997). Understanding governance: Policy networks, governance, reflexivity and accountability. Buckingham; Philadelphia: Open University Press.

Staritz, C., \& Morris, M. (2013). Local Embeddedness, upgrading and Skill development: global value chains and foreign direct investment in Lesotho's apparel industry. ÖFSE Working Paper 32. Vienna: ÖFSE. (Accessed October 9, 2012). Retrieved from http://www.oefse.at/Downloads/ publikationen/WP32_lesotho.pdf

Uzzi, B. (1996). The sources and consequences of embeddedness for the economic performance of organizations: The Network Effect. American Sociological Review, 61(4), 674-698.

Uzzi, B. (1997). Social structure and competition in interfirm networks: The paradox of embeddedness. Administrative Science Quarterly, 42, 35-67.

Yeung, W., C., \& Coe, M., N. (2015). Toward a dynamic theory of global production networks. Economic Geography, 91(11), 29-58. 


\section{Supporting Agencies:}

"This study was financed in part by the Coordenação de Aperfeiçoamento de Pessoal de Nível Superior Brasil (CAPES) - Finance Code 001”.

\section{Authors:}

1.Paulo Jordáo de Oliveira Cerqueira Fortes, PhD Student, Fundação de Ensino Inaciana (FEI), São Paulo, Brazil. E-mail: paulojordão@ufpi.edu.br.

ORCID

(D) 0000-0003-3873-8396

2. Caio Flavio Stettiner, Masters Degree in Education, Universidade Cidade de São Paulo, São Paulo, Brazil. E-mail: cstettiner@gmail.com

ORCID

(iD) 0000-0002-4479-7416

3. Marcelo T Okano, Post Doctorate in Production Engineering at UNIP, Post Doctorate in Production Engineering at UNESP - Faculdade de Engenharia de Guratingueta, São Paulo, Brazil.

E-mail: marcelo.okano@cps.sp.gov.br

ORCID

(iD) 0000-0003-1680-7821

\section{Contribution of each author}

Each author should take responsibility for at least one component of the paper. If the article is approved for publication, the authors should indicate in the diagram below, what was the contribution of each.

\begin{tabular}{lccc}
\hline Contribution & $\begin{array}{c}\text { Paulo Jordáo de Oliveira } \\
\text { Cerqueira Fortes }\end{array}$ & $\begin{array}{c}\text { Caio Flavio } \\
\text { Stettiner }\end{array}$ & $\begin{array}{c}\text { Marcelo T. } \\
\text { Okano }\end{array}$ \\
\hline 1. Definition of research problem & $\sqrt{ }$ & $\sqrt{ }$ & \\
2. Development of hypotheses or research questions (empirical studies) & $\sqrt{ }$ & & \\
3. Development of theoretical propositions (theoretical work) & $\sqrt{ }$ & $\sqrt{ }$ & $\sqrt{ }$ \\
4. Theoretical foundation/ Literature review & $\sqrt{ }$ & \\
5. Definition of methodological procedures & $\sqrt{ }$ & $\sqrt{ }$ & $\sqrt{ }$ \\
6. Data collection & $\sqrt{ }$ & $\sqrt{ }$ & $\sqrt{ }$ \\
7. Statistical analysis & $\sqrt{ }$ & $\sqrt{ }$ \\
8. Analysis and interpretation of data & $\sqrt{ }$ & $\sqrt{ }$ \\
9. Critical revision of the manuscript & $\sqrt{ }$ & & \\
10. Manuscript writing & $\sqrt{ }$ & & \\
11. Other (please specify which) & & & \\
\hline
\end{tabular}

This information will be available in publications as an end note in accordance with the criteria, policies and procedures for admission and permanence of scientific journals in SciELO Brazil Collection.

\section{Erratum}

Where was written:

"Review of Business Management, São Paulo, v.21, n.4, p.740-759, oct/dec. 2019"

Now read:

“Rev. Bras. Gest. Neg. São Paulo v.21, Special Issue. 2019 p. 740-759” 